\title{
Passive Immunization against Pyroglutamate-3 Amyloid- $\beta$ Reduces Plaque Burden in Alzheimer-Like Transgenic Mice: A Pilot Study
}

\author{
Jeffrey L. Frost ${ }^{a} \quad$ Bin Liu $^{a} \quad$ Martin Kleinschmidt ${ }^{b}$ Stephan Schilling ${ }^{b}$ \\ Hans-Ulrich Demuth ${ }^{b}$ Cynthia A. Lemere ${ }^{a}$ \\ ${ }^{a}$ Center for Neurologic Diseases, Brigham and Women's Hospital, Harvard Medical School, Boston, Mass., USA; \\ ${ }^{b}$ Probiodrug AG, Halle (Saale), Germany
}

\section{Key Words}

Alzheimer's disease $\cdot$ Pyroglutamate- 3 amyloid- $\beta$.

Monoclonal antibody $\cdot$ Immunotherapy $\cdot$ Transgenic mice

\begin{abstract}
Background: N-terminally truncated and modified pyroglutamate-3 amyloid- $\beta$ protein ( $p E 3-A \beta$ ) is present in most, if not all, cerebral plaque and vascular amyloid deposits in human Alzheimer's disease (AD). pE3-A deposition is also found in AD-like transgenic (tg) mouse brain, albeit in lesser quantities than general $A \beta$. $p E 3-A \beta$ resists degradation, is neurotoxic, and may act as a seed for $A \beta$ aggregation. Objective: We sought to determine if $\mathrm{pE} 3-\mathrm{A} \beta$ removal by passive immunization with a highly specific monoclonal antibody $(\mathrm{mAb})$ impacts pathogenesis in a mouse model of Alzheimer's amyloidosis. Methods: APPswe/PS1 $\Delta$ E9 tg mice were given weekly intraperitoneal injections of a new anti-pE3-A $\beta$ $\mathrm{mAb}$ (mAb07/1) or PBS from 5.8 to 13.8 months of age (prevention) or from 23 to 24.7 months of age (therapeutic). Multiple forms of cerebral $A \beta$ were quantified pathologically and biochemically. Gliosis and microhemorrhage were examined. Results: Chronic passive immunization with an anti$p E 3-A \beta$ mAb significantly reduced total plaque deposition and appeared to lower gliosis in the hippocampus and cerebellum in both the prevention and therapeutic studies. In-
\end{abstract}

\section{KARGER}

Fax +4161306 1234

E-Mail karger@karger.ch

www.karger.com
(C) 2012 S. Karger AG, Basel

$1660-2854 / 12 / 0104-0265 \$ 38.00 / 0$

Accessible online at:

www.karger.com/ndd soluble $A \beta$ levels in hemibrain homogenates were not significantly different between immunized and control mice. Microhemorrhage was not observed with anti-pE3-A $\beta$ immunotherapy. Conclusions: Selective removal of $p E 3-A \beta$ lowered general $A \beta$ plaque deposition suggesting a pro-aggregation or seeding role for $\mathrm{pE} 3-\mathrm{A} \beta$.

Copyright $\odot 2012$ S. Karger AG, Basel

\section{Introduction}

Alzheimer's disease (AD), the most common form of dementia, afflicts more than 30 million people worldwide. Amyloid- $\beta$ protein $(A \beta)$ is implicated in $A D$ pathogenesis [1]. N-terminally truncated and pyroglutamatemodified $A \beta$ peptide starting at residue $3(\mathrm{pE} 3-\mathrm{A} \beta)$ is abundant in cored and diffuse $A \beta$ deposits as well as vascular amyloid in $\mathrm{AD}$, presenilin-linked familial $\mathrm{AD}$, and Down syndrome brain [2-6]. pE3-A $\beta$ is formed upon removal of the first $2 \mathrm{~N}$-terminal residues of $\mathrm{A} \beta$ followed by cyclization by glutaminyl cyclase (QC; isoQC) to convert the third residue, glutamic acid, to pyroglutamate [7]. Pyroglutamate formation makes $\mathrm{A} \beta$ peptide more hydro-

\section{J.L. Frost and B. Liu contributed equally to this article.}

Cynthia A. Lemere, PhD

NRB 636F

77 Avenue Louis Pasteur

Boston, MA 02115 (USA)

Tel. +1 617525 5214, E-Mail clemere@ rics.bwh.harvard.edu 
phobic, speeding up its aggregation; $\mathrm{pE} 3-\mathrm{A} \beta$ peptide resists degradation, favoring formation of stable, neurotoxic aggregates [8-11]. It is unclear if $\mathrm{pE} 3-\mathrm{A} \beta$ peptide is present in early plaque deposition or if it accrues later. However, a correlation has been reported between pyroglutamate-modified $A \beta$ forms and severity of disease [12-14]. Taken together, these results indicate that $\mathrm{pE} 3$ $\mathrm{A} \beta$ peptide plays an important role in $\mathrm{AD}$ pathogenesis. Thereby, the N-terminal truncation and modification makes this peptide species a superior target for immunization. The primary advantage of such a strategy might be to capture and detoxify a particular $A \beta$ molecule without affecting the potential physiological function of fulllength $A \beta$. Here, we used passive immunization targeting $\mathrm{pE} 3-\mathrm{A} \beta$ in $\mathrm{AD}$-like transgenic (tg) mice to determine if selective removal of this toxic peptide impacts $\mathrm{AD}$ pathogenesis.

\section{Methods}

\section{Antibody Characterization}

Western blot analysis was performed as described previously [15]. The cross-reactivity was determined by surface plasmon resonance using a Biacore 3000. Different pyroglutamate-modified peptides were immobilized covalently on CM5 chips. The binding to these peptides was characterized by monitoring the association (540 s) and dissociation (540 s) of the monoclonal antibody $\mathrm{mAb} 07 / 1$.

\section{Animals}

APPswe/PS1 $\Delta$ E9 mice [16], harboring human APPswe (K595N/M596L) and PS1 $\Delta$ E9 (deletion of exon 9), were obtained from Jackson Lab (Bar Harbor, Me., USA), and bred in our colony with C57BL/6 mice. All animal use was approved by the Harvard Standing Committee for Animal Use and was in compliance with all state and federal regulations. Cerebral $A \beta$ plaque deposition and cerebral amyloid angiopathy are initiated at 5-6 months in this model [17].

\section{Passive Immunization}

Two trials were conducted in gender- and age-matched APPswe/PS1 $\Delta \mathrm{E} 9$ mice. A 'prevention' trial was initiated in 5.8-monthold mice ( \pm 0.38 SEM; anti-pE3-A $\beta$ mAb, $\mathrm{n}=6$; PBS control, $\mathrm{n}=$ 3 ), during the early stage of plaque deposition, and continued for 32 weeks. A 'therapeutic' trial was undertaken in 23-month-old mice ( \pm 0.25 SEM; anti-pE3-A $\beta, \mathrm{n}=4$; PBS control, $\mathrm{n}=4$ ) with robust cerebral $A \beta$ and $\mathrm{pE} 3-\mathrm{A} \beta$ plaque deposition and cerebral amyloid angiopathy, and continued for 7 weeks. Mice were vaccinated weekly by intraperitoneal injection of $200 \mu \mathrm{g}$ of a new mouse IgG1 mAb specific for $\mathrm{pE} 3-\mathrm{A} \beta$ [mAb07/1; Probiodrug AG, Halle (Saale), Germany] or $100 \mu$ l of PBS (as a control).

\section{Tissue Collection}

Mice were sacrificed by $\mathrm{CO}_{2}$ inhalation 1 week after the final immunization. Blood was collected via cardiac puncture followed by perfusion with $20 \mathrm{ml}$ PBS. The brain was removed and divided sagitally. One hemibrain was fixed for $2 \mathrm{~h}$ in $10 \%$ neutral buffered formalin and processed for paraffin embedding while the other was snap frozen and stored at $-80^{\circ} \mathrm{C}$ for biochemical analysis.

\section{Immunohistochemistry, Histology and Quantification}

Ten-micrometer paraffin sections were immunolabeled using the ABC ELITE method (Vector Laboratories, Burlingame, Calif., USA) as previously described [18]. The following antibodies were used for immunohistochemical analysis: anti-CD45 (1:5,000, Serotec, Raleigh, N.C., USA), anti-Iba-1 (1:500, Wako Chemicals, Richmond, Va., USA), anti-GFAP (1:1,000, DakoCytomation, Carpinteria, Calif., USA), rabbit polyclonal anti-A $\beta$ R1282 (1:1,000, gift from D. Selkoe, Boston, Mass., USA) and anti-pE3A $\beta$ mAb07/1 [1:1,000, gift from Probiodrug AG, Halle (Saale), Germany]. One-percent aqueous Thioflavin S (Sigma Aldrich, St. Louis, Mo., USA) was used to visualize fibrillar amyloid in plaques and blood vessels. Hemosiderin staining using 2\% ferrocyanide (Sigma) in $2 \%$ hydrochloric acid was used to detect microhemorrhages. Quantification of total R1282 immunoreactivity (IR), pE3-A $\beta$ IR and Thioflavin $S$ staining was performed using BIOQUANT image analysis (Nashville, Tenn., USA). The threshold of detection was held constant during analysis. The percent area occupied by R1282 IR, pE3-A $\beta$ IR or Thioflavin S labeling in the entire hippocampus and cerebellum was calculated for 3 equidistant sagittal sections $300 \mu \mathrm{m}$ apart per mouse. Vascular amyloid was evaluated semiquantitatively by 2 investigators (blinded to the treatment group) using the following criteria: ' 0 ' = no positive blood vessels; ' 1 ' = 1-5 positive blood vessels; ' 2 ' = 6-10 positive blood vessels, and ' 3 ' $=11$ or more positive blood vessels.

\section{Brain Homogenates and ELISAs}

Snap-frozen whole hemispheres were homogenized in 5 volumes of Tris-buffered saline containing a protease inhibitor cocktail (Roche, Indianapolis, Ind., USA). Homogenates were spun at $175,000 \mathrm{~g}$ for $30 \mathrm{~min}$ at $4^{\circ} \mathrm{C}$. The Tris-buffered saline pellet was resuspended in 10 volumes of guanidine buffer ( $5 \mathrm{M}$ guanidine $\mathrm{HCl}, 50 \mathrm{~mm}$ Tris, $\mathrm{pH}$ 8.0). Samples were mixed for $4 \mathrm{~h}$ at room temperature and stored at $-20^{\circ} \mathrm{C} . \mathrm{A} \beta(\mathrm{x}-42)$ and $\mathrm{pE}-\mathrm{A} \beta(3-42)$ were quantified as previously described [19] using commercial ELISA kits (IBL, Hamburg, Germany).

Statistical Analyses

The Mann-Whitney U test (Prism 4.0 Software, GraphPad, San Diego, Calif., USA) was used to compare the results of immunized and PBS control mice. Significant differences were defined as $\mathrm{p}<0.05$.

\section{Results}

\section{Anti-pE3-A $\beta$ mAb Characterization}

The specificity of antibody $\mathrm{mAb} 07 / 1$ was assessed by a combination of Western blot and surface plasmon resonance analysis (fig. 1). The antibody showed no crossreactivity with full-length $A \beta(1-x)$ or truncated, noncyclized $A \beta(3-x)$ in Western blot analyses. Moreover, pyroglutamate-modified neuropeptides or hormones were 
not recognized by $\mathrm{mAb} 07 / 1$, suggesting a very high specificity of the molecule without potential of side effects. For immunization, the antibody was purified from cultures of mouse hybridoma cells and then sterile-filtered in PBS. The concentration range for injection was 2-2.5 $\mathrm{mg} / \mathrm{ml}$.

\section{Passive Anti-pE3-A $\beta$ Vaccination Lowered Total $A \beta$}

Deposition in a Prevention Trial

$\mathrm{A} \beta$ deposition begins in the hippocampus, neocortex and cerebellum at 5-6 months in APPswe/PS1 $\Delta \mathrm{E} 9$ mice and increases with age [17]. By 6 months, a small subset of mostly compacted plaques contains $\mathrm{pE} 3-\mathrm{A} \beta$; this subset increases with age in proportion to general $A \beta$ deposition (data not shown). In this study, mice were immunized weekly with the highly specific anti-pE3-A $\beta$ $\mathrm{mAb} 07 / 1$ starting at 5.8 months of age, during the early stages of $A \beta$ deposition. Following 32 weeks of vaccination, total $\mathrm{A} \beta$ deposition (including plaques and cerebral amyloid angiopathy) was reduced in the hippocampus and cerebellum in the approximately 14 month-old treated mice compared to age- and gender-matched PBS controls (table 1; fig. 2). In the hippocampus, $\mathrm{pE} 3-\mathrm{A} \beta$ and general $A \beta(R 1282)$ IR were reduced by $35 \%(p=0.04)$ and $18 \%(\mathrm{p}=0.01)$, respectively, while Thioflavin-S-positive fibrillar amyloid was reduced by $50 \%(\mathrm{p}=0.02)$ in immunized mice when normalized to PBS controls. In the cerebellum, $\mathrm{pE} 3-\mathrm{A} \beta$ and general $\mathrm{A} \beta$ IR were lowered by $76 \%(\mathrm{p}=0.0004)$ and $52 \%(\mathrm{p}=0.005)$, respectively, while Thioflavin-S-positive fibrillar amyloid was $43 \%$ less $(\mathrm{p}=0.13, \mathrm{n} . \mathrm{s}$.) in immunized mice when normalized to the PBS control mice. The absolute values, listed in table 1 , strongly suggest that passive immunization against $\mathrm{pE} 3-\mathrm{A} \beta$ reduced more than $\mathrm{pE} 3-\mathrm{A} \beta$ alone. For example, an absolute reduction of $2.4 \%$ in general $A \beta$ (R1282) IR was observed in the hippocampus, whereas the absolute amount of $\mathrm{pE} 3-\mathrm{A} \beta$ in the PBS control group was much lower $(0.61 \%$; table 1$)$. Similar reductions were observed in the cortex but were not quantified (data not shown). Semiquantitative analysis of vascular amyloid (scored 0-3) was similar in the hippocampus between PBS control and $\mathrm{pE} 3-\mathrm{A} \beta$ vaccinated mice (R1282:0.89 \pm 0.11 SEM vs. $0.59 \pm 0.12, \mathrm{p}=0.11$; $\mathrm{pE} 3-\mathrm{A} \beta: 0$ vs. $0, \mathrm{p}=$ n.s.). In the cerebellum, vascular amyloid was reduced by vaccination (R1282: $2.11 \pm 0.26$ vs. $1.47 \pm 0.15, \mathrm{p}=0.03$; pE3-Aß: $0.33 \pm 0.17$ vs. $0.17 \pm 0.09, \mathrm{p}=0.24)$. Microhemorrhages were absent in both groups of approximately 14 -month-old mice.

No significant differences between immunized and control mice were observed in $\mathrm{pE}-\mathrm{A} \beta(3-42)$ and $\mathrm{A} \beta(\mathrm{x}-$

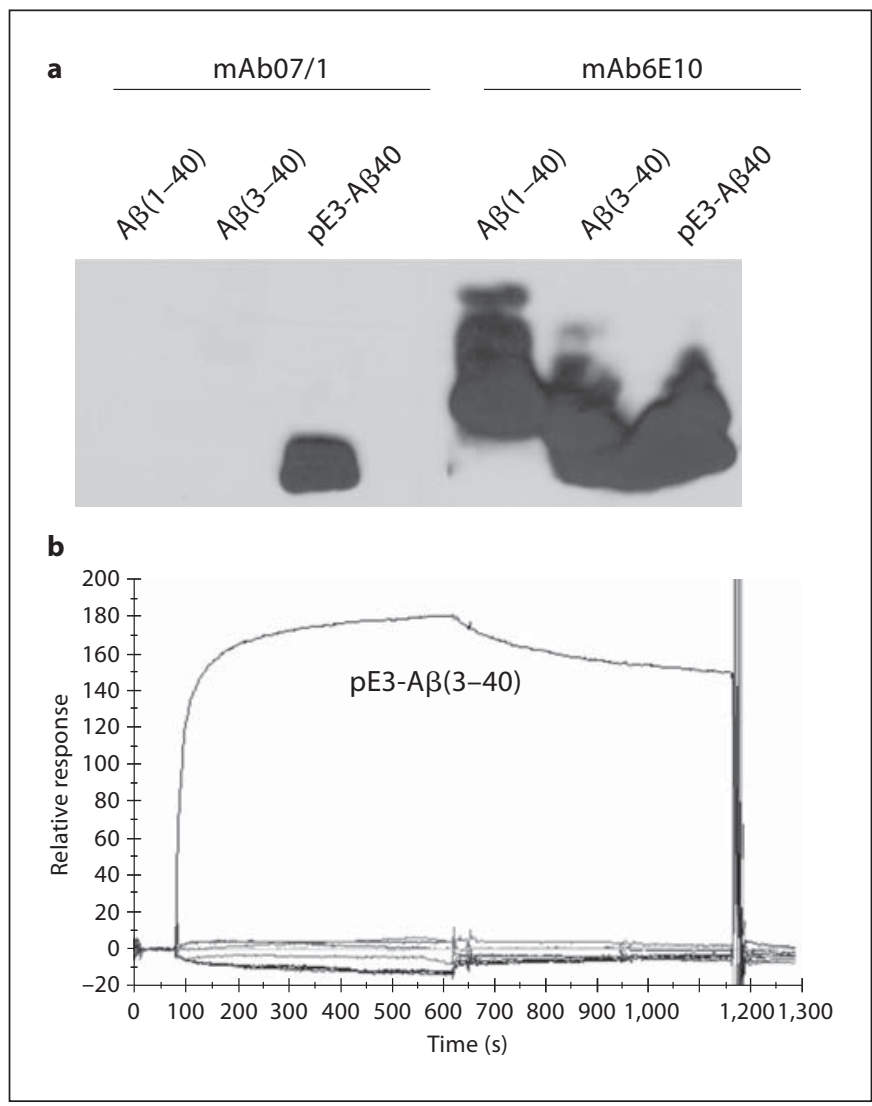

Fig. 1. Characterization of $\mathrm{pE} 3-\mathrm{A} \beta \mathrm{mAb} 07 / 1$. a Western blot of $A \beta(1-40), A \beta(3-40)$ and $p E 3-A \beta(3-40)$, detected with $\mathrm{mAb} 07 / 1$ or mAb6E10. Peptides (20 ng each) were separated in gels containing $8 \mathrm{M}$ urea. The anti-pE3-A $\beta \mathrm{mAb}$ does not detect the truncated precursor or full-length A $\beta$. $\mathbf{b}$ Analysis of antibody binding using surface plasmon resonance. The peptides were covalently linked and the antibody applied in a buffered solution. Significant binding of $\mathrm{mAb} 07 / 1$ was only observed with $\mathrm{pE} 3-\mathrm{A} \beta(3-40)$ immobilized on the surface. Other peptides analyzed are: MCP-1 and 2; gastrin; GnRH; neurotensin; orexin; TRH; the N-terminus of collagen, and fibronectin.

42) levels in guanidine $\mathrm{HCl}$-extracted hemibrain homogenates; $\mathrm{pE}-\mathrm{A} \beta(3-42)$ was approximately $0.2 \%$ of $\mathrm{A} \beta(\mathrm{x}-$ 42). Microgliosis (Iba-1 and CD45 IR) and astrocytosis (GFAP IR) appeared to be attenuated in the immunized mice compared to PBS controls.

\section{Passive Anti-pE3-A $\beta$ Vaccination Reduced Plaque \\ Burden in the Absence of Microhemorrhage in a \\ Therapeutic Trial}

Twenty-three-month-old, plaque-bearing APPswe/ PS1 $\Delta$ E9 mice were passively immunized weekly for 7 weeks. The percent areas occupied by general A $\beta$ IR and 
Fig. 2. In a prevention study initiated during the early stage of plaque deposition, weekly passive immunization of APPswe/ $\mathrm{PS} 1 \Delta \mathrm{E} 9$ mice with anti-pE3-A $\beta$ mAb07/1 from 5.8 to 13.8 months of age significantly reduced $\mathrm{pE} 3-\mathrm{A} \beta$ as well as general $\mathrm{A} \beta$ (R1282 IR) and fibrillar amyloid (Thioflavin $S$ ) deposition in the hippocampus (a, b) and cerebellum $(\mathbf{c}, \mathbf{d})$ compared to that in PBS control mice. Immunohistochemical results (a, c) and Thioflavin S labeling were quantified by image analysis $(\mathbf{b}, \mathbf{d})$. Absolute values are provided in table 1 . Scale bars, $200 \mu \mathrm{m}$. p values: ${ }^{*} \mathrm{p}<0.05$; ${ }^{* *} \mathrm{p}<0.01 ;{ }^{* * *} \mathrm{p}<0.001 ;$ n.s. $=$ nonsignificant ( $\mathrm{p}=0.089)$.

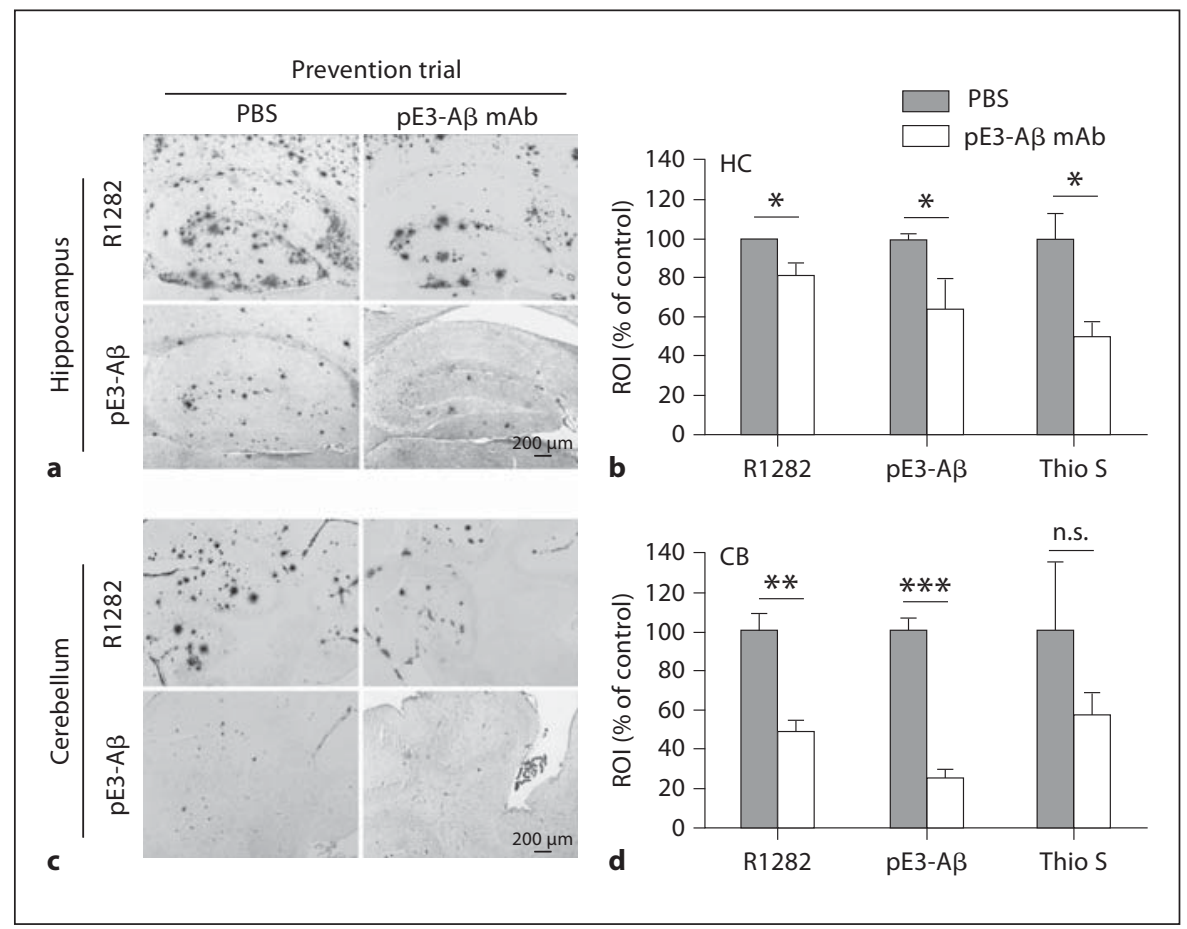

Table 1. Absolute values of percent labeling within the area of interest

\begin{tabular}{lrrll}
\hline & PBS & $\begin{array}{l}\text { A } \beta \text {-pE3 } \\
\text { vaccinated }\end{array}$ & $\begin{array}{l}\text { Percent } \\
\text { reduction }\end{array}$ & $\begin{array}{l}\text { p } \\
\text { value }\end{array}$ \\
\hline $\begin{array}{l}\text { Prevention trial } \\
\text { Hippocampus } \\
\text { R1282 IR }\end{array}$ & $13.0 \pm 0.06$ & $10.6 \pm 0.88$ & $18.20 \pm 6.82$ & 0.0119 \\
pE3-A & $0.61 \pm 0.02$ & $0.39 \pm 0.10$ & $35.33 \pm 15.64$ & 0.04 \\
Thio S & $0.72 \pm 0.10$ & $0.36 \pm 0.06$ & $49.57 \pm 8.11$ & 0.02 \\
Cerebellum & & & & \\
R1282 IR & $3.4 \pm 0.32$ & $1.7 \pm 0.20$ & $51.56 \pm 5.96$ & 0.005 \\
pE3-A & $0.36 \pm 0.02$ & $0.09 \pm 0.02$ & $75.55 \pm 4.78$ & 0.0004 \\
Thio S & $0.17 \pm 0.06$ & $0.1 \pm 0.02$ & $43.49 \pm 12.02$ & 0.13 \\
\hline Therapeutic trial & & & & \\
Hippocampus & & & & \\
R1282 IR & $10.0 \pm 0.76$ & $7.5 \pm 0.66$ & $24.80 \pm 6.47$ & 0.025 \\
pE3-A & $2.2 \pm 0.47$ & $1.5 \pm 0.18$ & $33.84 \pm 7.90$ & 0.11 \\
Thio S & $1.4 \pm 0.25$ & $0.7 \pm 0.22$ & $48.52 \pm 14.25$ & 0.04 \\
Cerebellum & & & & \\
R1282 IR & $3.9 \pm 0.29$ & $1.5 \pm 0.27$ & $62.36 \pm 7.20$ & 0.0005 \\
pE3-A & $1.0 \pm 0.14$ & $0.6 \pm 0.09$ & $40.95 \pm 8.90$ & 0.03 \\
Thio S & $0.76 \pm 0.11$ & $0.47 \pm 0.06$ & $38.34 \pm 8.46$ & 0.06 \\
\hline
\end{tabular}

${ }^{1}$ Percent reduction normalized to mean PBS control value.
pE3-A $\beta$ IR, respectively, were higher in the 24.7-monthold versus 14-month-old PBS control mice at the end of each study, especially in the cerebellum (data not shown). Overall, therapeutic passive anti-pE3-A $\beta$ immunization reduced both general $A \beta$ and $p E 3-A \beta$ IR (table 1; fig. 3), similar to the reductions seen in the prevention study. In the hippocampus, $\mathrm{pE} 3-\mathrm{A} \beta$ and general $\mathrm{A} \beta$ (R1282) IR were reduced by $34 \%$ (n.s.) and $25 \%(\mathrm{p}=0.03)$, respectively, while Thioflavin-S-positive fibrillar amyloid was reduced by $49 \%(\mathrm{p}=0.04)$ in the immunized mice when normalized to the PBS control mice. In the cerebellum, $\mathrm{pE} 3-\mathrm{A} \beta$ and general $\mathrm{A} \beta$ IR were reduced by $41 \%(\mathrm{p}=$ $0.03)$ and $62 \%(\mathrm{p}=0.0005)$, respectively, while Thioflavin $\mathrm{S}$ amyloid was lowered by $38 \%(\mathrm{p}=0.06$, trend) in immunized mice when normalized to PBS control mice. Although we measured total deposition, reductions in plaque load accounted for the majority of differences in immunized compared to control mice; vascular amyloid deposits were unchanged relative to the age-matched control mice. Semiquantitative analysis of vascular amyloid (scored 0-3) was similar in the hippocampus between PBS control and $\mathrm{pE} 3-\mathrm{A} \beta$ vaccinated mice (R1282: $0.83 \pm 0.11$ SEM vs. $0.75 \pm 0.13, p=0.37 ; \mathrm{pE} 3-\mathrm{A} \beta: 0.83$ \pm 0.17 vs. $0.75 \pm 0.13, \mathrm{p}=0.41)$. In the cerebellum, vascular amyloid was reduced by vaccination (R1282: $2.5 \pm$ 0.19 vs. $2.5 \pm 0.15, \mathrm{p}=0.44 ; \mathrm{pE} 3-\mathrm{A} \beta: 1.83 \pm 0.21$ vs. 1.83 
Fig. 3. In a therapeutic study initiated well after the onset of cerebral $A \beta$ deposition and gliosis, weekly passive immunization with anti-pE3-A $\beta$ mAb07/1 in 23-monthold APPswe/PS1 $\Delta \mathrm{E} 9$ mice for 7 weeks resulted in the attenuation of $\mathrm{pE} 3-\mathrm{A} \beta$ and general $A \beta$ (R1282 IR) deposition as well as fibrillar amyloid (Thioflavin S) in the hippocampus $(\mathbf{a}, \mathbf{b})$ and cerebellum $(\mathbf{c}, \mathbf{d})$ compared to PBS control mice. Immunohistochemical results $(\mathbf{a}, \mathbf{c})$ and Thioflavin $S$ labeling were quantified by image analysis $(\mathbf{b}, \mathbf{d})$. Absolute values are provided in table 1 . Scale bars, $200 \mu \mathrm{m}$. p values: ${ }^{*} \mathrm{p}<$ $0.05 ;{ }^{* *} \mathrm{p}<0.001 ;$ n.s. $=$ nonsignificant $(\mathrm{p}=0.11) ; \mathrm{p}=0.06$ (strong trend).

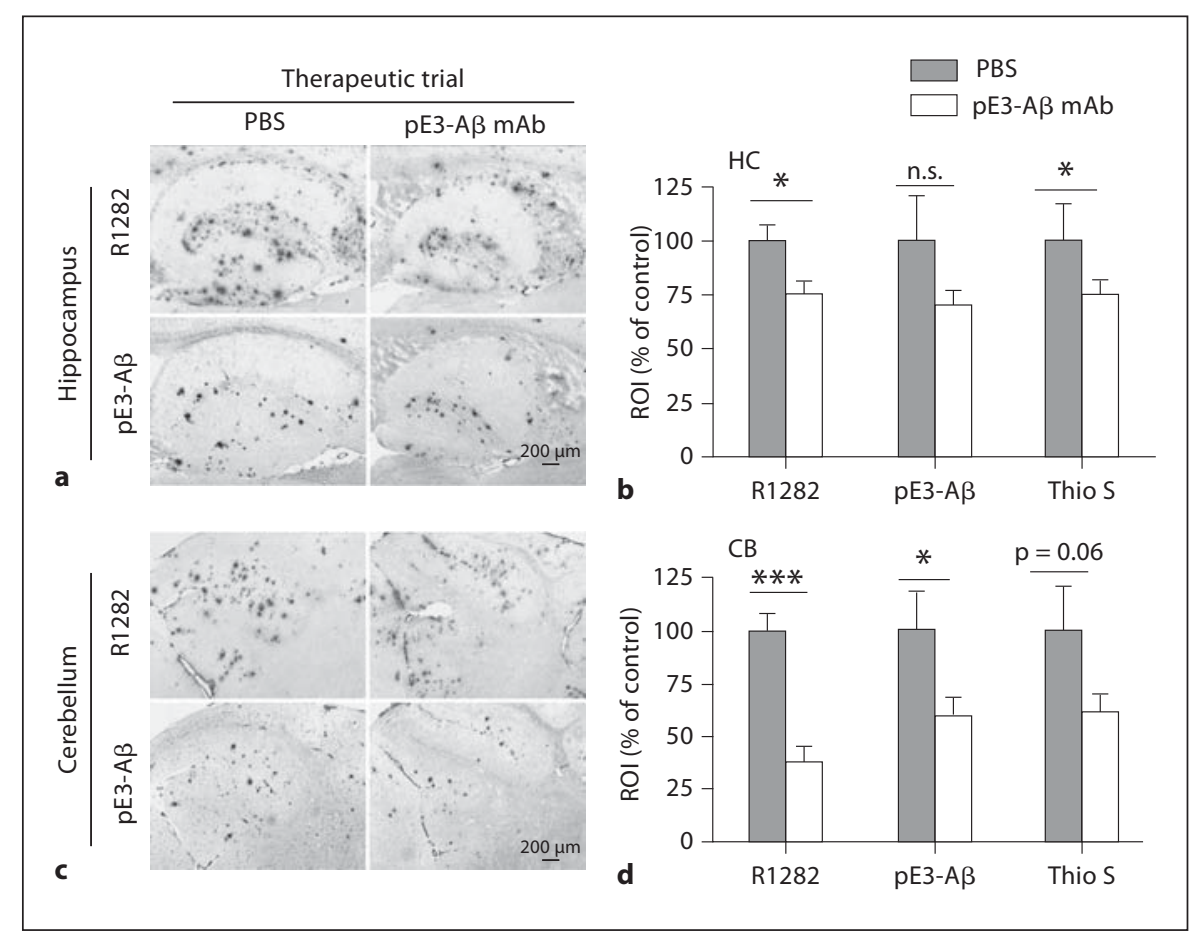

$\pm 0.17, \mathrm{p}=0.49$ ). Microhemorrhages were not observed in either the immunized or control mice at 24.7 months of age.

Biochemical levels of $A \beta(x-42)$ and $p E-A \beta(3-42)$ were slightly reduced with immunization but did not reach significance (data not shown). As in the prevention study, microgliosis and astrocytosis appeared to be lower in the immunized mice compared to the PBS control mice, possibly reflecting the reduced plaque burden.

\section{Discussion}

APPswe/PS1 $\triangle E 9$ mice showed increasing deposition of general $A \beta, p E 3-A \beta$, and fibrillar amyloid in the cortex, hippocampus and cerebellum with aging (i.e. from approx. 14 to 24.7 months of age), although pE3-A $\beta$ was detected in much lower quantities at both ages compared to general $A \beta$. In this pilot study, using a small number of mice per group, passive immunization with a highly specific anti-pE3-A $\beta$ mAb reduced all 3 types of deposits in the hippocampus and cerebellum in both a prevention study initiated in the early stage of plaque deposition and in a therapeutic study initiated in aged mice with robust $\mathrm{A} \beta$ deposition and gliosis. The percent of plaque reduction was similar between the prevention and the thera- peutic trial, even though the absolute level of plaque deposition was higher in the older mice. However, even in the therapeutic study, the absolute amount of general $A \beta$ and fibrillar amyloid deposits were reduced beyond the amount expected from clearance of $\mathrm{pE} 3-\mathrm{A} \beta$ deposits alone as shown in table 1 , suggesting that $\mathrm{pE} 3-\mathrm{A} \beta$ removal may prevent new plaque formation. In both studies, $A \beta$ deposit lowering by the $\mathrm{pE} 3-\mathrm{A} \beta \mathrm{mAb}$ was greater in the cerebellum than the hippocampus (and the cortex, data not shown). This may be due, in part, to the lower abundance of $A \beta$ deposition in the cerebellum relative to that in the hippocampus and cortex. Possibly, plaque deposition in the cerebellum appears later or the antibodies had more access to the cerebellum than other brain regions. It is still unclear, though, why the biochemical measurements of insoluble $A \beta(x-42)$ and $p E-A \beta(3-42)$ levels did not reflect the quantitative immunohistochemical results. Potential reasons are that the homogenates were derived from entire hemibrains, but the pathological analysis was done on small brain regions in thin sections, i.e. using a total of 3 equidistant brain sections per mouse. Moreover, different antibodies were used in the immunohistochemical and ELISA analyses, which may have contributed to the discrepancy we observed. For example, the ELISAs used here quantify $A \beta(x-42)$ and $p E-A \beta(3-42)$, including low levels of $\mathrm{P} 3$ fragments, but not $A \beta$ ending 
at residue 40. Immunohistochemistry was performed using R1282 pAb that detects general $A \beta$ and $m A b 07 / 1$ (specific for $A \beta$ starting at pyroglutamate at residue 3 ), both of which detect $A \beta$ ending at residues 40 and 42 . Lastly, interanimal variability and the low numbers of animals used in these preliminary studies may have played a role as well.

Overall, our results confirm and extend those published recently by Wirths et al. [20] in which 6 weeks of passive immunization with their IgG2b pE3-A $\beta$ oligomer-specific mAb, 9D5, led to reduced cerebral A $\beta$ levels and plaque burden, and improved performance on the elevated plus maze test for anxiety in four 4.5-month-old 5XFAD tg mice compared to 4 control mice. Plans are underway to study the effects of passive immunization with the anti-pE3-A $\beta \mathrm{mAb} 07 / 1$ used in our study (that recognizes monomeric, oligomeric and fibrillar $\mathrm{pE} 3-\mathrm{A} \beta$ ) on cognition, as well as AD pathogenesis, in a large cohort of AD-like tg mice.

What are the implications of these studies? Selective removal of $\mathrm{pE} 3-\mathrm{A} \beta$ peptides, especially early in $\mathrm{AD}$ pathogenesis, may lower deposition of $\mathrm{pE} 3-\mathrm{A} \beta$, general $\mathrm{A} \beta$, and fibrillar amyloid, as $\mathrm{pE} 3-\mathrm{A} \beta$ may play a role in the aggregation and/or deposition of multiple $A \beta$ species in brain. Therefore, selective targeting of this particularly toxic $A \beta$ species by immunotherapy may be an effective way to prevent or treat $\mathrm{AD}$ in humans in whom $\mathrm{pE} 3$ $A \beta$ IR is present in most, if not all, cerebral $A \beta$ deposits.

\section{References}

1 Selkoe DJ: Alzheimer's disease: genes, proteins, and therapy. Physiol Rev 2001;81:741766.

-2 Saido TC, Iwatsubo T, Mann DMA, Shimada H, Ihara Y, Kawashima S: Dominant and differential deposition of distinct $\beta$-amyloid peptide species, $A \beta_{\mathrm{N} 3(\mathrm{p} 3)}$, in senile plaques. Neuron 1995;14:457-466.

3 Lemere CA, Blusztajn JK, Yamaguchi $H$, Wisniewski T, Saido TC, Selkoe DJ: Sequence of deposition of heterogeneous amyloid beta-peptides and APO E in Down syndrome: implications for initial events in amyloid plaque formation. Neurobiol Dis 1996; 3:16-32.

-4 Lemere CA, Lopera F, Kosik KS, Lendon CL, Ossa J, Saido TC, Yamaguchi H, Ruiz A, Martinez A, Madrigal L, Hincapie L, Arango-L JC, Anthony DC, Koo E, Goate A, Selkoe DJ, Arango-V JC: The E280A presenilin 1 Alzheimer mutation produces increased A 42 deposition and severe cerebellar pathology. Nat Med 1996;2:1146-1150.

5 Miravalle L, Calero M, Takao M, Roher A, Ghetti B, Vidal R: Amino-terminally truncated $\mathrm{A} \beta$ peptide species are the main component of cotton wool plaques. Biochemistry 2005;44:10810-10821.

6 Wirths O, Bethge T, Marcello A, Harmeier A, Jawhar S, Lucassen P, Malthaup G, Brody $\mathrm{DL}$, Esparza $\mathrm{T}$, Ingelsson $\mathrm{M}$, Kalimo $\mathrm{H}$, Lannsfelt L, Bayer TA: Pyroglutamate Abeta pathology in APP/PS1KO mice, sporadic and familial Alzheimer's disease cases. J Neural Transm 2010;117:85-96.

7 Schilling S, Hoffmann T, Manhart S, Hoffmann M, Demuth H: Glutaminyl cyclases unfold glutamyl cyclase activity under mild acid conditions. FEBS Lett 2004;563:191196.
8 Saido TC, Yamao-Harigaya W, Iwatsubo T, Kawashima S: Amino- and carboxyl-terminal heterogeneity of beta-amyloid peptides deposited in human brain. Neurosci Lett 1996;215:173-176.

-9 Schilling S, Lauber T, Schaupp M, Manhart S, Scheel E, Bohm G, Demuth H-U: On the seeding and oligomerization of the pGluamyloid peptides (in vitro). Biochemistry 2006;45:12393-12399.

$10 \mathrm{He}$ W, Barrow C: The A $\beta$ 3-pyroglutamyl and 11-pyroglutamyl peptides found in senile plaques have greater $\beta$-sheet forming and aggregation propensities in vitro than full length $A \beta$. Biochemistry 1999;38:1087110877.

11 Wirths O, Breyhan H, Cynis H, Schilling S, Demuth H-U, Bayer T: Intraneuronal pyroglutamate-Abeta 3-42 triggers neurodegeneration and lethal neurological deficits in a transgenic mouse model. Acta Neuropathol 2009;118:487-496.

12 Guntert A, Dobeli H, Bohrmann B: High sensitivity analysis of amyloid-beta peptide composition in amyloid deposits from human and PS2APP mouse brain. Neuroscience 2006; 143:461-475.

13 Piccini A, Zanusso G, Borghi R, Noviello C, Monaco S, Russo R, Damonte G, Armirotti A, Gelati M, Giordano R, Zambenedetti P, Russo C, Ghetti B, Tabaton M: Association of a presenilin 1 S170F mutation with a novel Alzheimer disease molecular phenotype. Arch Neurol 2007;64:738-745.

$\checkmark 14$ Piccini A, Russo C, Gliozzi A, Relini A, Vitali A, Borghi R, Giliberto L, Armirotti A, D’Arrigo C, Bachi A, Cattaneo A, Canale C, Torrassa S, Saido T, Markesbery W, Gambetti $\mathrm{P}$, Tabaton M: $\beta$-Amyloid is different in normal aging and in Alzheimer's disease. J Biol Chem 2005;280:34186-34192.
15 Cynis J, Scheel E, Saido TC, Schilling S, Demuth HU: Amyloidogenic processing of the amyloid precursor protein: evidence of a pivotal role of glutaminyl cyclase in generation of pyroglutamate-modified amyloid-beta. Biochemistry 2008;47:7405-7413.

16 Jankowsky J, Fadale D, Anderson J, Xu G, Gonzales V, Jenkins N, Copeland N, Lee M, Younkin L, Wagner S, Younkin S, Borchelt D: Mutant presenilins specifically elevate the levels of the 42 residue beta-amyloid peptide in vivo: evidence for augmentation of a 42-specific gamma secretase. Hum Mol Genet 2004;13:159-170.

17 Garcia-Alloza M, Robbins E, Zhang-Nunes S, Purcell S, Betensky R, Raju S, Prada C, Greenberg S, Bacskai B, Frosch M: Characterization of amyloid deposition in the APPswe/PS1dE9 mouse model of Alzheimer's disease. Neurobiol Dis 2006;24:516-524.

- 18 Lemere CA, Spooner ET, Leverone JF, Mori C, Clements JD: Intranasal immunotherapy for the treatment of Alzheimer's disease: Escherichia coli $\mathrm{LT}$ and LT(R192G) as mucosal adjuvants. Neurobiol Aging 2002;23:991-1000.

19 Schilling S, Zeitschel U, Hoffmann T, Heiser U, Franke M, Kehlen A, Holzer M, HutterPaier B, Prokesch M, Windisch M, Jagla W, Schlenzig D, Lindner C, Rudolph T, Reuter G, Cynis H, Montage D, Demuth H-U, Rossner S: Glutaminyl cyclase inhibition attenuates pyroglutamate $A \beta$ and Alzheimer's diseaselike pathology. Nat Med 2008;14:1106-1111.

20 Wirths O, Erck C, Martens H, Harmeier A, Geumann C, Jawhar S, Kumar S, Multhaup G, Walter J, Ingelsson M, Degerman-Gunnarsson M, Kalimo H, Huitinga I, Lannfelt L, Bayer TA: Identification of low molecular weight pyroglutamate $A \beta$ oligomers in Alzheimer disease. J Biol Chem 2010;285: 41517-41524. 